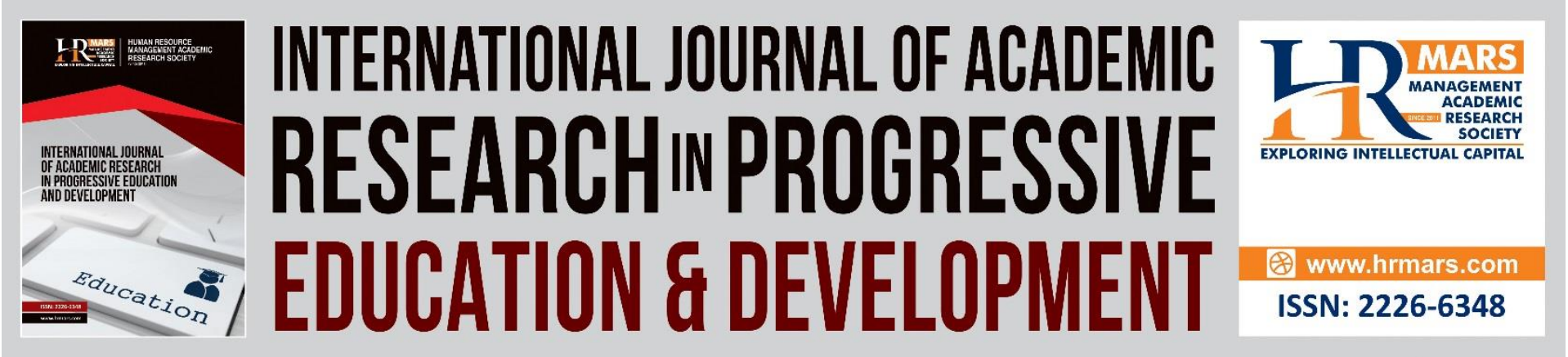

\title{
Piloting A New Curriculum: Teachers' Perspective
}

\section{Lydia Kanake Kobiah}

To Link this Article: http://dx.doi.org/10.6007/IJARPED/v10-i4/11709

DOI:10.6007/IJARPED/v10-i4/11709

Received: 08 October2021, Revised: 11 November 2021, Accepted: 29 November 2021

Published Online: 21 December2021

In-Text Citation: (Kobiah, 2021)

To Cite this Article: Kobiah, L. K. (2021). Piloting A New Curriculum: Teachers' Perspective. International Journal of Academic Research in Progressive Education and Development, 10(4), 237-247.

Copyright: (C) 2021The Author(s)

Published by Human Resource Management Academic Research Society (www.hrmars.com)

This article is published under the Creative Commons Attribution (CC BY 4.0) license. Anyone may reproduce, distribute, translate and create derivative works of this article (for both commercial and non-commercial purposes), subject to full attribution to the original publication and authors. The full terms of this license may be seen

at: http://creativecommons.org/licences/by/4.0/legalcode

Vol. $10(4)$ 2021, Pg. 237- 247

http://hrmars.com/index.php/pages/detail/IJARPED

JOURNAL HOMEPAGE

Full Terms \& Conditions of access and use can be found athttp://hrmars.com/index.php/pages/detail/publication-ethics 


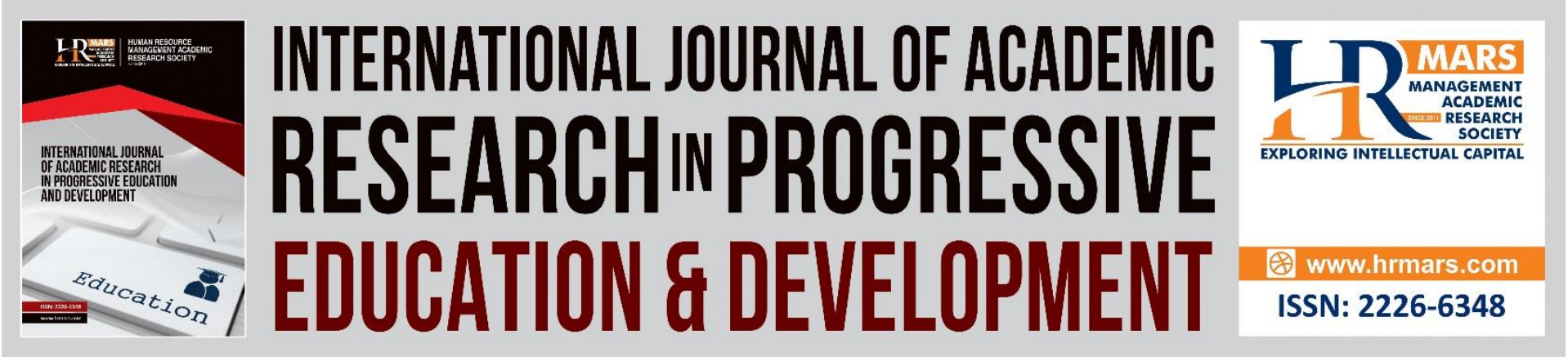

\title{
Piloting A New Curriculum: Teachers' Perspective
}

\author{
Lydia Kanake Kobiah \\ School of Education, Kabarak University, P. O. 20157, Kabarak, Kenya \\ Email: Ikobiah@kabarak.ac.ke
}

\begin{abstract}
Teacher participation in curriculum development has been the subject of considerable educational research in recent years, but the participation of teachers in curriculum piloting has received limited empirical attention. The purpose of this study was to establish teachers' perspective of their involvement in piloting of the new curriculum and implementation of secondary school curriculum in Kenya. The study employed descriptive survey research design. A sample of 342 teachers who included 194 males and 148 females participated in the study. Questionnaires for teachers and an interview guide for principals were employed in data collection. The collected data was analysed by use of both descriptive and inferential statistics. The study findings established that there was statically significant relationship between teachers' involvement in curriculum piloting and implementation of secondary school curriculum. The study recommends that teachers should be involved in the planning and development of the curriculum in all stages for effective implementation. The Kenya institute of Curriculum Development (KICD) should lay better strategies to involve teachers in curriculum piloting for effective delivery. It is hoped that the findings of the study would provide all educational stakeholders with the feedback on whether there is a gap between curriculum policy on paper and what happens in practice. The study is hoped to give impact on teachers and curriculum developers on how they would work together in curriculum construction for effective implementation. Studies on innovative models of curriculum development should be conducted with a view to proposing alternative models that would enable more teachers and other stakeholders to participate actively in curriculum development process.
\end{abstract}

Keywords: Teacher Participation, Teacher Perspective, Curriculum Piloting, Curriculum Implementation, Secondary School Curriculum

\section{Introduction}

Curriculum development is a multi-step process of creating andimproving a course taught at a school or university (Skyepack, 2019). It covers the entire spectrum of curriculum construction, ranging from the initial conceptualization and planning; to design, development and implementation, to evaluation and revision (Kobiah, 2015). According to Mafoa (2012), a developed curriculum package consists of textbooks, instructional aids and sometimes even tests for students and teachers' self- evaluation. It also includes teachers' 
guides containing a comprehensive syllabus, the rationale for choices of content items, teaching goals and teaching suggestions.

Curriculum Piloting refers to the process of introducing the planned curriculum in a smallscale to select schools to test the feasibility of the program before it is implemented on a large scale in all schools. Pilot testing or field try-out enable the curriculum developers to identify which sections of the curriculum works and are maintained and which sections need to be strengthened or dropped (I-Tech, 2008). Whenever a curriculum is written as in books, course materials, modules or the whole curricular programme, there is need to have a tryout or field - testing. This process gathers empirical data to support whether the materials or the curriculum is useful, relevant, reliable and valid.

Mosothwane (2012) avers that teacher involvement in curriculum development empowers them to use a variety of teaching methods and materials that could promote effective learning. Curricular activities acquired through participation in the development projects could serve teachers in the implementation of externally developed curriculum materials including commercially prepared textbooks (Ben-Peretz, 1990).

The Alberta Teachers Association (2012) notes that implementation of a new curriculum requires that a draft programme and resources be evaluated through a pilot project. Piloting should assess teaching methods, appropriateness of content, materials, issues of timing and flow, and general effectiveness of the training (I-TECH, 2008). By trying out the curriculum, it is easy to identify the strengths, weaknesses and challenges that may be faced in the implementation of the new curriculum. Various gaps are addressed before it can be introduced in all schools in the country. Studies show that many educational policy makers do not support the try out as they see the step as an unnecessary delay in introducing the new curriculum (Obai, 1999; Oluoch, 1982). In selecting pilot schools, efforts is made to choose schools that offer as much variety as possible for example small versus large schools, town versus rural and schools with most teachers trained versus those that rely heavily on untrained teachers (Shiundu \& Omulando, 1992). The representativeness of pilot schools should enable the new curriculum and the curriculum materials and equipment to be made more suitable for a majority of schools in the country than would have been the case if the pilot was conducted in a homogenous or haphazard selection of schools (Oluoch, 1982).

In Kenya, the Kenya Institute of Curriculum Development (KICD) has adopted the phasing in - phasing out pre-test strategy since 2003 where the new curriculum is simultaneously introduced at several points in the education ladder for example, new curriculum and curriculum support materials is introduced at class one, class five and form one (KICD, 2014; KIE, 2007). UNESCO (2009) observed that in many contexts, there has been a tendency for curriculum to be developed by curriculum specialists and given to teachers to be delivered as a product. In these circumstances, the teacher may feel de- professionalised and disempowered, becoming little more than a curriculum delivery technician. Carl (2009) asserts that teacher participation in curriculum piloting would enable teachers to reflect on the curriculum and propose possible amendments, give a critical interpretation, evaluation of learning areas or subjects' position in the school curriculum, selection of suitable and relevant textbooks and other resources. Participants in pilots experience significant personal and professional development and can take ownership of the proposed change. In an evaluation study by KICD to determine the effectiveness of its inputs, processes, and outputs, only $40 \%$ of curriculum developers said they were happy with the quality of their product, one of the main reasons being that curriculums are hurriedly done and lacked 
internal quality control mechanisms (KICD, 2015). Putting the curriculum into operation therefore requires an implementing agent who is the teacher (Bediako, 2019). It gives them the opportunity to test curriculum products and give a critique on various aspect of the curriculum before it is rolled out in schools.

\section{Statement of the Problem}

In Kenya, curriculum development process is highly centralised with Kenya Institute of Curriculum Development (KICD) being the main government agency charged with the responsibility of developing the curriculum through the course and subjects panels. The ministry of education view teachers as mere implementers of the development curriculum. The basic component of the curriculum, the syllabus, is designed elsewhere and given to those for whom it is intended. The accompanying learning and teaching materials are also developed, examined, validated and approved for use in the schools by respective subject panels in order to facilitate curriculum piloting and implementation.

Research has revealed that a wide gap exist between centrally developed curriculum plans and local school situations (Asiachi \& Okech, 1992; Mlanga, Okao, 2006). These authors further argue that there existed patterns of discrepancies especially between the intended curriculum and the implemented curriculum which called for deeper reflections. Literature on teachers' views on their role in curriculum piloting and its impact on curriculum implementation is scanty. This study sought to establish the relationship between teachers' perspective of their role in curriculum piloting and effective implementation of secondary school curriculum in Kenya.

\section{Research Objective}

To establish whether there is a relationship between teachers' role in curriculum piloting and implementation of secondary school curriculum in Kenya.

\section{Research Hypothesis}

Ho: There is no statistically significant relationship between teachers' role in curriculum piloting and implementation of secondary school curriculum in Kenya

\section{Methodology}

This study adopted descriptive survey research design and was conducted in Meru and Nairobi Counties, Kenya. The target population was 3146 secondary school teachers comprising of 1781 males and 1365 females drawn from 351 secondary schools in Nairobi and Meru Counties. The study employed stratified random sampling procedures to select a representative sample of 342 teachers who proportionately included 194 males and 148 females. Data collection methods included Interview guide for principals and questionnaire for teachers. Both descriptive and inferential statistics were used in data analysis. Descriptive statistics involved calculation of means, frequency counts and percentages. For inferential statistics, chi square was used to test the hypotheses and was computed and tested for significance at $\propto=0.05$ level of significance. Qualitative data was organized and presented in narrative and discussion form. 
DEVELOPMENT

Vol.10,No.4, 2021,E-ISSN:2 226-6348 @ 2021 HRMARS

\section{Results and Discussion}

Respondents were requested to indicate the extent of their participation in curriculum piloting during curriculum development process. The information was analysed by determining the mean and standard deviation on five items on a 5 -point Likert scale where: To a Greater Extent $=5$, To Some Extent $=4$, Undecided $=3$, To a Small Extent $=2$ and Not at All $=1$. Table 1 presents the results

Table 1

Teachers' Participation in Curriculum Piloting

\begin{tabular}{|c|c|c|c|}
\hline Participation & $\mathrm{N}$ & $\mathrm{M}$ & SD \\
\hline $\begin{array}{l}\text { Participated in assessing the relevance of the proposed } \\
\text { curriculum }\end{array}$ & 272 & 1.60 & 1.16 \\
\hline $\begin{array}{l}\text { Participated in the advisory and orientation of teachers } \\
\text { involved in piloting }\end{array}$ & 272 & 1.44 & 1.05 \\
\hline $\begin{array}{l}\text { Involved in the actual piloting of the proposed curriculum in } \\
\text { the selected schools }\end{array}$ & 272 & 1.42 & 1.02 \\
\hline Participated in in-service training before piloting & 272 & 1.43 & 1.05 \\
\hline $\begin{array}{l}\text { Participated in approving the curriculum support materials for } \\
\text { the new curriculum }\end{array}$ & 272 & 1.49 & 1.10 \\
\hline Overall mean & 272 & 1.47 & 0.99 \\
\hline
\end{tabular}

From Table 1, the study established that teachers did not at all participate in curriculum piloting $(M=1.47)$. Results also indicate that teachers never participated in assessing the relevance of the proposed curriculum $(M=1.60)$ and that teachers did not at all participate in the actual piloting of the proposed curriculum in the selected schools ( $M=1.42)$. Lack of participation in curriculum piloting could have a negative influence on the effective implementation of secondary school curriculum in Kenya. The information gathered from the principals supported the views that teachers rarely participated in curriculum piloting. Principals' views are given in Excerpt 1.

\section{Excerpt 1}

Researcher: How are teachers involved in curriculum piloting during the curriculum development process?

Respondent 1: Teachers are not involved in this process at all. Curriculum is implemented immediately without seeking the opinion of the implementers.

Respondent 2: When there are changes, Heads of Department and Subject Leaders from big schools may be invited for training as Trainer of Trainers (ToT) for one or two days so that they can also carry out the training of other teachers in their respective sub counties. This does not work out well as many of them do not grasp intended concepts effectively.

Respondent 3: Piloting is done by a few selected schools and few teachers are involved. We are never aware of these schools and the criteria used to select them are not known. It is a closed system. 
DEVELOPMENT

Vol.10,No.4, 2021,E-ISSN:2 226-6348 @ 2021 HRMARS

Respondent 4: Few teachers are involved in "phasing in, phasing out" process employed by the KICD to introduce new changes in the curriculum. A new curriculum is introduced in different classes. There are no regular and scheduled in-service and orientation programs to continuously enhance the capacity of teachers to interpret and implement the curriculum effectively

Respondent 5: No participation at all from my school. I doubt whether there is any piloting conducted by KICD

The findings show that teachers are only involved in curriculum piloting to a small extent probably through the Phasing in - phasing out process employed by the KICD since 2002 (KIE, 2005). The in- service training carried is not adequate and only a few teachers are recruited for training. This may contribute to poor implementation of secondary school curriculum. The Alberta Teachers Association (2012); Nasib (2018) opine that pilot testing the curriculum enables the curriculum developers to consider how best to achieve the objectives, establish the efficacy of the learning resources and the kind of expertise needed by the implementers for effective implementation. Piloting also allows the identification of the major problems that would arise during implementation, work out solutions to them before the new curriculum materials go into schools (Nasib, 2018). Teachers who are experts in their teaching areas should therefore be given an opportunity to participate in curriculum piloting in order to help improve the quality of the curriculum.

The researcher sought perspective from the teachers on their participation in curriculum piloting and effective implementation of secondary school curriculum. The information was analysed by determining the mean and standard deviation on six items on 5 point Likert scale where: Strongly Agree $=5$, Agree $=4$, Undecided=3, Disagree $=2$ and Strongly Disagree $=1$. The results of the analysis are presented in Table 2 .

Table 2

Curriculum Piloting and Effective Implementation of Secondary School Curriculum

\begin{tabular}{|c|c|c|c|}
\hline Opinion & $\mathrm{N}$ & $\bar{M}$ & SD \\
\hline $\begin{array}{l}\text { Participation enables teachers to identify the } \\
\text { weaknesses and strengths of the curriculum and } \\
\text { propose changes }\end{array}$ & 272 & 4.54 & 0.65 \\
\hline $\begin{array}{l}\text { Participation in curriculum orientation and advisory } \\
\text { services leads to effective implementation }\end{array}$ & 272 & 4.35 & 0.70 \\
\hline $\begin{array}{l}\text { Participation in piloting increases teachers' knowledge } \\
\text { in the selection of curriculum support materials during } \\
\text { implementation }\end{array}$ & 272 & 4.32 & 0.72 \\
\hline $\begin{array}{l}\text { Participation in in-service training leads to effective } \\
\text { implementation of the curriculum }\end{array}$ & 272 & 4.35 & 0.74 \\
\hline $\begin{array}{l}\text { Teachers do not implement the curriculum effectively } \\
\text { without participating in curriculum piloting }\end{array}$ & 272 & 2.64 & 1.46 \\
\hline Overall Mean & 272 & 4.04 & 0.54 \\
\hline
\end{tabular}

From Table 2, study findings show that in overall, teachers agreed that teacher participation in the curriculum piloting exercise would have a positive effect on the implementation of 
secondary school curriculum $(M=4.04)$. Teachers moderately agreed that they did not implemented the curriculum effectively without participating in curriculum piloting activities $(M=2.64)$. These findings were supported by information gathered from the interviews with principals who were also in agreement that participation in curriculum piloting among teachers was a critical factor in effective implementation of the secondary school curriculum. Principals' descriptions are given in Excerpt 2.

\section{Excerpt 2}

Researcher: Do you think there is any relationship between teacher participation in curriculum piloting and implementation of secondary school curriculum? Explain your answer.

Respondent 5: Yes. When teachers are involved in piloting, they are able to identify gaps in the curriculum which would lead to either review or change at an early stage

Respondent 11:Teachers would understand the process and give critique or suggest what will work and what will not work. We would not be teaching a lot of irrelevances like we do today

Respondent 14: Yes. One gets to know the content and to familiarize oneself with materials and methodologies before national wide implementation. It helps reduce anxiety among teachers.

Respondent 6: Participation creates ownership of the whole process and motivates teachers to work even harder because they feel it's their process.

Researcher: How can teachers be empowered to participate in future?

Respondent 10: It is the responsibility of the Ministry of Education and the teachers' employer - Teachers Service Commission, (TSC) to ensure that teachers are trained regularly to enable them get new skills for effective participation Proper mechanisms should be put in place to enable teacher participation in the whole process because in the end, they hold the key to children' future.

The findings in excerpt 2 tend to suggest that even though teachers participated in curriculum piloting to a small extent, they strongly believed that participation in curriculum piloting had a positive effect on effective implementation of secondary school curriculum. The principals noted that participation in curriculum piloting would enable teachers to give a critique or suggest what will work and what will not in order to reduce irrelevances in the curriculum. Teachers also called on the government to provide regular training to teachers for active participation in all stages of curriculum development. In line with the study findings, Carl (2009) noted that participation in piloting would enable teachers to reflect on the curriculum and propose possible amendments, give a critical interpretation, evaluation of the learning areas/subjects position in the school curriculum, selection of suitable and relevant textbooks and other resources. The Alberta Teachers Association (2012) states that piloting assures teachers and schools that indeed the curriculum materials are ready for use. According to Carl (2009), teachers who participated in curriculum revision brought a new intelligence to their teaching. This suggests that there is a positive relationship between 
teachers' participation in curriculum piloting and effective implementation of secondary school curriculum.

Chi square test was carried out to establish whether there existed a statistically significant relationship between teachers' participation in curriculum piloting and implementation of the secondary school curriculum in Kenya. The results of the analysis are presented in Table 3

Table 3

Chi Square Test Results on Participation in Curriculum Piloting and Curriculum Implementation

\begin{tabular}{|c|c|c|c|}
\hline Statement & Chi-Square & Df & Asymp. Sig. \\
\hline $\begin{array}{l}\text { Participation enables teachers to identify the } \\
\text { weaknesses and strengths of the curriculum and } \\
\text { propose changes }\end{array}$ & 264.62 & 4 & .000 \\
\hline $\begin{array}{l}\text { Participation in curriculum orientation and } \\
\text { advisory services leads to effective implementation }\end{array}$ & 362.63 & 4 & .000 \\
\hline $\begin{array}{l}\text { Participation in piloting increases teachers } \\
\text { knowledge in the selection of curriculum support } \\
\text { materials during implementation }\end{array}$ & 314.51 & 4 & .000 \\
\hline $\begin{array}{l}\text { Participation in in-service training leads to } \\
\text { effective implementation of the curriculum }\end{array}$ & 324.25 & 4 & .000 \\
\hline $\begin{array}{l}\text { Teachers do not implement the curriculum } \\
\text { effectively without participating in curriculum } \\
\text { piloting activities }\end{array}$ & 50.24 & 4 & .000 \\
\hline Overall Chi Square & 282.12 & 15 & 0.000 \\
\hline
\end{tabular}

Findings in Table 3 show that there was a statistically significant relationship between teachers participation in curriculum piloting and implementation of secondary school curriculum, $\left[\chi^{2}(4, N=272)=282.12, p=0.00<0.05\right]$. Thus the null hypothesis which stated that there was no statistically significant relationship between teachers' participation in curriculum piloting and implementation of secondary school curriculum in Kenya was rejected. In a pilot study carried out in Greece by Klonari et al (2014) on implementation of the new Greek Geography curriculum in primary schools, 30\% of primary school teachers who participated in the study felt completely familiar with its goals because the training seminars they underwent assisted them in forming a clear picture of learning outcomes, activities and teaching methods proposed in the new curriculum. This suggests a positive relationship between teacher participation in curriculum piloting and effective implementation of the curriculum. It also suggests the importance of preparing the teachers through in-service training before implementation of any curriculum for effective implementation. Training seminars helped teachers to respond effectively to the pilot implementation of the new Geography Curriculum in Greece (Klonari et al., 2014)

\section{Conclusion}

This study established that there was statistically significant relationship between teacher participation in curriculum piloting and implementation of secondary school curriculum. However, there was minimal involvement of teachers in piloting the curriculum which led to 
anxiety and confusion during the implementation stage. The study established that participation in piloting would enable teachers to gain new insights into the curriculum and identify gaps which may impede effective implementation of the curriculum at an early stage for correction. Due to the top- down model of curriculum development followed by $\mathrm{KICD}$, curriculum development process is still largely centrally-controlled and the experiences and talents of teachers are untapped and under-utilized in this vital process. This implies that curriculum development process should involve a shift of decision-making from the centre to the periphery which will cause a change in teachers' and administrators' roles, involving them in greater decision making regarding curriculum construction. Establishing school - based committees, Sub-county, County and then national committees would enable teachers to be involved in curriculum piloting and air their opinions regarding curriculum issues that may need to be addressed before large scale implementation. This would lead to greater understanding of learning objectives and the skills needed by implementers to achieve the learning goals. This would probably improve the quality of education in Kenya.

This study provides valuable feedback to educational policy makers and curricula developers on the existing gap between curriculum policy on paper and what happens in practice. The findings of the study may impact on how teachers and curriculum developers work together in curriculum construction for effective implementation of curriculum by teachers in schools. It is hoped that the study will add to the pool of academic knowledge in the area of curriculum development especially with regard to the relationship between teachers' participation in curriculum piloting and implementation of secondary school curriculum. It could also act as a springboard for future studies in other aspects of curriculum.

\section{Recommendations}

This study recommends that teachers should be involved in planning and development of the curriculum in all stages. Policy makers need to acknowledge the experience and talents of the teachers more in the curriculum development process. Furthermore, the KICD should lay better strategies to involve more teachers in the curriculum development process. This can be done by redefining the curriculum development unit at KICD as an extension of the school system, thus providing more teachers to serve in it for a period of time. Also, curriculum development should be decentralized to local levels for easier participation from schools, sub-counties, counties and finally the national level taking into considerations all relevant contributions by various stake-holders. Studies on curriculum models followed by KICD should be conducted with a view to proposing alternative models that would enable more teachers and other stakeholders to participate fully in curriculum development process.

\section{Acknowledgement}

I would like to thank the Almighty God for His watchful guidance and provision especially good health to undertake and complete this work. My sincere gratitude to my supervisors, my family and Friends for support, encouragement and prayers during my doctoral studies. To my esteemed respondents, I say thank you. You all made it happen. 
INTERNATIONAL JOURNAL OF ACADEMIC RESEARCH IN PROGRESSIVE EDUCATION AND

DEVELOPMENT

Vol.10,No.4, 2021,E-ISSN:2226-6348 @ 2021 HRMARS

\section{References}

Alberta Education. (2012). Chapter1: Curriculum Development Processes. http://www.education.alberta.ca/media/.../d-chapter1.pdf. Alberta. Retrieved on 29/7/2014

Asiachi, J. A., \& Okech, J. G. (1992). Curriculum Development for Schools. Nairobi. Educational Research and Publications Ltd.

Bediako, S. (2019). Models and Concepts of Models of Curriculum Implementation. Some Definitions and Influence of Implementation. DOI:10.13140/RG.2.2.17850.24009. University of South Coast, ResearchGate. Retrieved on 2/12/2021

Ben-Peretz, M. (1990). The Teacher-Curriculum Encounter: Freeing Teachers from the Tyranny

of Texts. Albany, NY: SUNY Press.

Carl, A. E. (2009). Teacher Empowerment through Curriculum Development: Theoryinto Practice ( $3^{\text {rd }} \mathrm{Ed}$ ) at http//www.books. Google. Co.ke/books?/sbn= 0702177512

I-TECH. (2008). Piloting a Curriculum. Washington. Retrieved on 28/3/2013 and 5/12/2021 www.go2itec.org/resources/technical..guides/TIG3.PilotingCurriculum./file.

K. I. C. D. (2014). An Evaluation of KICD Curriculum Development to Determine the Effectiveness of its inputs, process and outputs. Research Services No 119. Nairobi. KICD

K. I. C. D. (2015). Secondary Summative Evaluation. http.//www.kicd. Ac.ke/93departments/153 - secondary summative - evaluation.ntml.

K. I. E. (2007). Report on Monitoring of the Implementation of Phase Four of the Revised Secondary School Curriculum. K.I.E. Research Report Series No. 85. Nairobi. K.I.E.

K. I. E. (2005). Report on Monitoring of the Implementation of Phase Two of the Revised Secondary School Curriculum. Research Report Series No.80. Nairobi: K.I.E.

Klonari, A. I., Mandrikas, A., Melista, A., \& Tzoura, M. (2014). One Year pilot Implementation of the New Greek Geography Curriculum in Primary Education. European Journal of Geography, 5(1), 81-97. Available at

http://www.eurogeographyjournal.eu/articles/6.ONE\%20YEAR\%20PILOT\%2OIMPLEMENTATIO N\%20OF\%20NEW\%20GREEK\%20GEOGRAPHY\%20CURRICULUM\%20IN\%20PRIMARY\%20EDUC ATION\%20\%20final\%20version.axil.pdf.

Kobiah, L. K. (2015). Relationship between Teachers' Participation in Curriculum Development and Implementation of Secondary School curriculum in Kenya. Unpublished PhD Thesis: Chuka University.

Mafoa, T. L. (2012). Teachers Perceptions on the Implementation of the New (2000) Business Studies Curriculum. Master of Teaching and learning Thesis-University of Canterbury. Retrieved on 14/4/2013 from http: // www. Ir. canterbury. ac. nz/ bitstream/ 10092/7530/1/Thesis-fultext.pdf.

Mlanga, A. (1987). An Investigation into the Perceptions of Selected High School Teachers in Nairobi Regarding the Procedures Involved in Curriculum Development in Kenya. P.G.D.E. Thesis. Nairobi: Kenyatta University.

Mosothwane, M. (2012). The role of Senior Secondary School Mathematics Teachers in the Development of Mathematics Curriculum in Botswana. International Journal of Scientific Research in Education, 5(2), 117-129. Available at http://www.ijsre.com.Retrieved on 15/4/2013 


\section{DEVELOPMENT}

Vol.10,No.4, 2021,E-ISSN:2 226-6348 @ 2021 HRMARS

Nasib, T. (2018). Curriculum Development: What is the Roe of Piloting in Curriculum Development?

https://mysominotes.wordpress.com/2018/01/20/curriculum-development-what-isthe-role-of-piloting-in-developing-a-concise-and-comprehensive-curriculum/.

Retrieved on $3 / 12 / 2021$

Obai, G. (1999). The Teachers' Role in Curriculum Development in Kenya: a study of Perceptions held by Secondary Schools in Kisii District. Unpublished M.Ed Thesis. Nairobi- Kenya: Kenyatta University

Oluoch, G. P. (1982). Essentials of Curriculum Development. Nairobi:

Elimu: Bookshop Ltd.

Okao, M. E. (2006). Teachers' Perceptions towards the Teaching of Economics in Secondary Schools: Implications on the Business Studies Curriculum in Kenya. Egerton University: Unpublished M.ED Thesis.

Shiundu, J. S., \& Omulando, S. J. (1992). Curriculum: Theory and Practice in Kenya. Nairobi: Oxford University Press

Skyepack. (2019). Curriculum Development: Complete Overview \& 6 Steps. https://www.skyepack.com/post/curriculum-development.Retrieved On 3/12/2021

UNESCO -IBE. (2009). Process of Curriculum Implementation. www.lbe.unesco.org/fileadmin/user-upload/COPs/pagesdocuments/Resourcepacks/TTCD/sitemap/module-7/module. Retrieved on 25/10/15. 